\title{
The Effect of The Role of Leadership on Organizational Culture and Internal Control Effectiveness
}

\author{
Francisca Devi Anita ${ }^{1 *}$ and Dwi Setiawan ${ }^{2}$ \\ ${ }^{1,2}$ Universitas Indonesia, Depok, Indonesia
}

\begin{abstract}
Good internal control can provide confidence that an organization can achieve its goals with ethical actions. The phenomenon that occurs at this time shows that organizational culture is the main factor causing the emergence of huge scandals that afflict an organization that can prevent the organization from achieving its objectives. Risk in culture occurs when the behavior of members of an organization is not in line with the behavior that the organization wants to instill, causing unethical behavior that can hinder the achievement of goals and influence internal control of the organization.

At present, the organizational culture is an essential area within the scope of internal audit work. The role of the current internal auditor is expected to provide adequate assurance regarding one element of risk culture, namely the role of the leader (tone from the top) that has been carried out by following the values and ethics instilled by the organization. Leaders have a significant influence on the formation of culture and internal control systems in organizational units so that the role of internal auditors can provide confidence that the culture formed does not negatively affect overall organizational behavior becomes important.

Keywords: Internal Control, Organizational Culture, Risk Culture, The Role Of An Internal Auditor, The Tone From The Top.
\end{abstract}

\section{Introduction}

Internal control has been effective if the organization has adequate confidence that shows the vision, mission, goals, and targets of the organization can achieve what has been determined through appropriate methods of ethics, provide financial information that is reliable and trustworthy, complies with applicable regulations, and can safeguard his assets (Moeller, 2009). The Directorate General of Taxation (DGT) is one of the public sector organizations that began to carry out bureaucratic reform in Indonesia since 2002 by carrying out internal organizational reforms (DJP, 2012). However, based on the DGT's 2017 Performance Report, it shows that DGT has not yet achieved the stated organizational goals of optimizing state revenues in line with the organization's vision and mission (Kemenkeu, 2017). The result from the performance report shows that DGT's internal control has not run effectively because the vision, mission, and goals and targets of the organization have not been achieved according to what has been determined.

The risk of organizational culture can cause internal control that has not been able to work correctly, and this has been proven by the cases that occurred in Enron, Wells Fargo, and Worldcom. DGT as an organization that collects state revenues is inseparable from the risk of organizational culture, namely with the emergence of unethical behavior as an example that occurred in the case of Gayus Tambunan (Lumbanrau, 2016). The first component of the internal control framework is the control environment, where the role of top management is critical to creating the tone at the top in an organization, including a standard setting (COSO, 2013). Unethical behavior has led to an increase in organizational culture to become the biggest scandal of the company today, and proven in a survey conducted by The IIA (2013) that the area is one of the top three areas chosen by the Head of Internal Audit to add resources to auditing corporate culture and ethics. The aim is to provide adequate assurance to top leaders that the organizational culture which organization set it has been carried out thoroughly in all organizational units. The presence of risk culture can lead to activities

* Corresponding author. Email address : fdevi_anita@yahoo.co.id 
that are not in line with organizational values or policies (CIIA, 2014b), and endanger the health of the company and long-term employees (CIIA, 2016). Not only does it reduce employee morale, but an unhealthy organizational culture can also eliminate customers, damage reputation, and destroy corporate value (Clayton \& Wisdom, 2019).

The bureaucratic reforms carried out by the DGT include Tax Reformation Volume I, Volume II, and Volume III. Volume II one of them emphasizes the improvement of internal control, while Volume III conducted since 2017 focuses on five main points, namely organizations, human resources, information technology and databases, business processes, and tax regulations (Cahyasari, 2018). Tax Reform Volume III will be carried out well when the increase in internal control carried out in Volume II of Tax Reform has been effective. The purpose of this study will be to evaluate whether the internal controls carried out so far have been effective by considering the risk of organizational culture that could endanger the organization as a whole. What is the role of the top leadership in forming "the tone at the top" in the organizational culture that they want to instill in the internal control of the organization so far? Then how does the role of internal auditors so far have been able to provide understanding to the leaders that the culture they wish to cultivate in reality has already implemented in their everyday action?

Previous studies show that leadership (Rizaldi, 2015), leader support (Rusnindita \& Baridwan, 2017), individual characteristics of top-level leaders (Lu \& Cao, 2018), and organizational integrity (Shu, Chen, Lin, \& Chen, 2018) has a vital role in the control environment in internal control. The control environment is one element of the internal control framework issued by the Committee of Sponsoring Organizations of the Treadway Commission (COSO) where the role of top leaders in determining the "tone at the top" is very important to instill the desired organizational culture (COSO, 2013). An influential organizational culture can be used to build employee commitment, is a tool in controlling and motivating employees so that performance is increased (Owoyemi \& Ekwoaba, 2014).

This research is research in the form of case studies that will be conducted at the DGT, especially at one of the KPP Pratama Jakarta. Retrieving the required data will be done by using semi-structured interviews with the DGT's internal audit department, and samples of several employees in the KPP unit. Then the results of the data obtained will be analyzed qualitatively using a theoretical approach such as the theory of planned behavior in conducting behavior analysis, literature, and related supporting documents.

This research was conducted to provide an overview of how the top leadership role in the organization is essential in supporting effective internal control of an organization. Then, for internal auditors after getting an understanding of the existence of risk culture, they can enter the area in each audit program.

This study will consist of an introduction, literature review, research methods, results and research analysis, and conclusions and suggestions.

\section{Literature Study/Hypotheses Development}

\section{Internal Control, Organizational Culture, and the Role of Top Leaders}

The most basic internal control framework according to COSO (2013) is control environment, which is a set of standards, processes, and structures as the basis for carrying out internal controls in the organization. The control environment itself contains organizational integrity and values, which can be used as a measure by top leaders in carrying out their responsibilities to oversee organizational governance. In the environment of controlling the role of the leadership of both the commissioner and the board of directors in establishing "the tone at the top" is essential, and becomes a standard of behavior that is expected to occur within the organization (COSO, 2013). The tone from the top is the first step for the board and senior management in creating organizational values and cultural risks expected in an organization, and how their behavior reflects the values they want to instill (CIIA, 2014b). Organizational success starts from the top because generally, executives can set culture and lead by giving 
examples of behavior (IIA, 2016). By giving examples of behavior shows that internal control is influenced by people, not just standard policies and procedures but how their behavior in each organizational unit can influence internal control itself (COSO, 2013). The fundamental concept can be seen in the definition of internal control issued by (COSO, 2013) that internal control is a process that is influenced by the board of directors, management, and other personnel, in order to provide adequate assurance that the organization's goals could be achieved.

Employee behavior can be influenced by organizational culture when organizational culture gets stronger then employee commitment increases and is a way to control and motivate employees so that their performance increases (Owoyemi \& Ekwoaba, 2014). A simple understanding of culture is "the way we usually do things where we are" (The IIA, 2016a). The simple understanding according to The IIA is in line with the explanation according to Owoyemi \& Ekwoaba (2014). That through continuous collaboration as a group, with differences in cultural beliefs, values and ethics merge into one together developing behavior, values, beliefs, habits, norms, and so on which then become something usual for the organization, and ultimately form the culture of the organization itself. Based on this understanding, it explains that organizational culture is a value and ethics that want to be instilled in the organization so that it can influence employee behavior, but the organizational culture itself can be formed from the fusion of differences in the values and ethics of each employee that develops into organizational beliefs and habits. This understanding is in accordance with the explanation from Professor Sir Ian Kennedy, that is, organizational culture refers to the value of the organization and how to translate it into daily behavior, but the behavior that is consistent with the value of the organization is more aspirational compared to the actual values in the organization (CIIA, 2014b).

Research conducted by Domnisoru, Ogarca, \& Dragomir (2017) concludes that one source of soft control is organizational culture. It can motivate and connect employees with the entities they work in, but on the other hand, internal control can also influence organizational culture by changing several elements such as regulations, habits, and ways of communicating that are part of the culture of the organization itself. There can be no doubt that the foundation of the entire internal control system is an organizational culture that can replace the elements of the control environment itself in the internal control framework according to COSO because the elements in the control environment are the organization's culture itself (Domnisoru et al., 2017).

\section{Risk Culture and the Role of Internal Audit}

At present, the culture has risen to become the most prominent corporate scandal due to the continued bad behavior of the company that continues to occur, one of which is at Volkswagen and Germany's Commerzbank AG (The IIA, 2016a) after previously seen in the Enron case, WorldCom and Wells Fargo. Those cases show that organizational culture is the root cause of the many scandals that occur, which can have a tremendous impact on individuals, organizations, and even the state. Risk culture is a term that describes the values, beliefs, knowledge, and understanding of risks that are shared by a group of people who share the same goal, especially employees or team groups within an organization (CIIA, 2014b). If these risks cannot be appropriately managed, especially risk culture, it will lead to a behavior that is not in line with organizational policies and procedures. Unethical behavior is the leading cause of organizational failures (The IIA, 2016a). Elements of risk culture according to FSB, EY, PWC, and Deloitte, namely: 


FSB
- Tone from the top
-Accountability
- Effective
communication
and Challenge
- Incentives
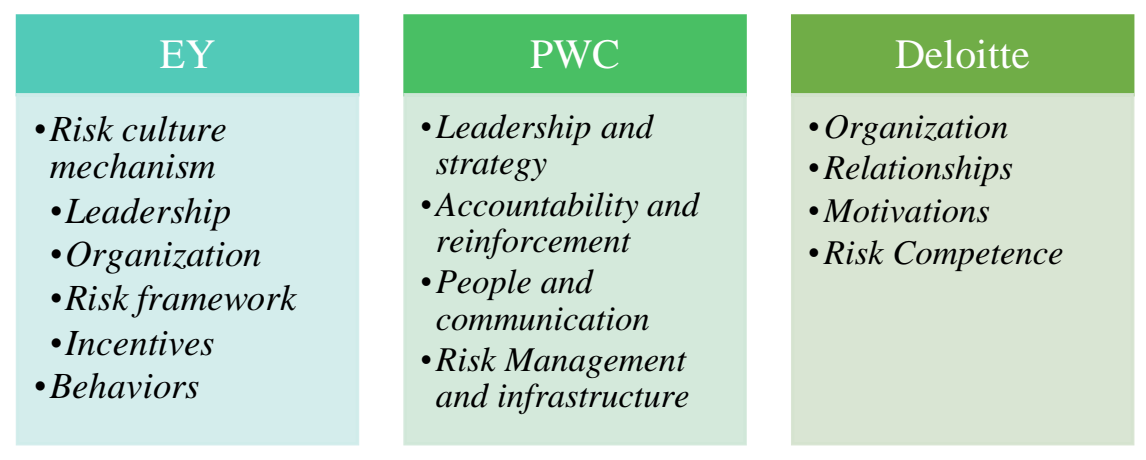

Figure 1 Elements of Risk Culture

Source: Guidance on Supervisory Interaction with Financial Institutions on Risk Culture (FSB, 2014, p. 3-4); Risk Culture: The role of internal audit (EY, 2015, p.4); Auditing risk culture: art or science? (PWC, 2009, p.6); Cultivating a Risk Intelligent Culture (Deloitte,

$$
\text { 2012, P.3) }
$$

Therefore, The IIA financial services Code 2013 emphasized the importance of culture, especially in the financial services sector, and recommended that internal audits incorporate into its scope of work the risks and cultural controls within the organization, and evaluate whether the organization has been in accordance with integrity when interacting with customers and other related parties (CIIA, 2014a). The risk of organizational culture that can threaten the organization in the long run results in the role of internal audit becoming more critical for evaluating and evaluating the current organizational culture. Conduct an audit of the culture of support in generating value for stakeholders by encouraging organizations to manage risk proactively and immediately make corrections to the failure of internal control before the situation worsens (The IIA, 2016a). The following are three lines of defense and audit culture according to IIA (The IIA, 2016b), namely:

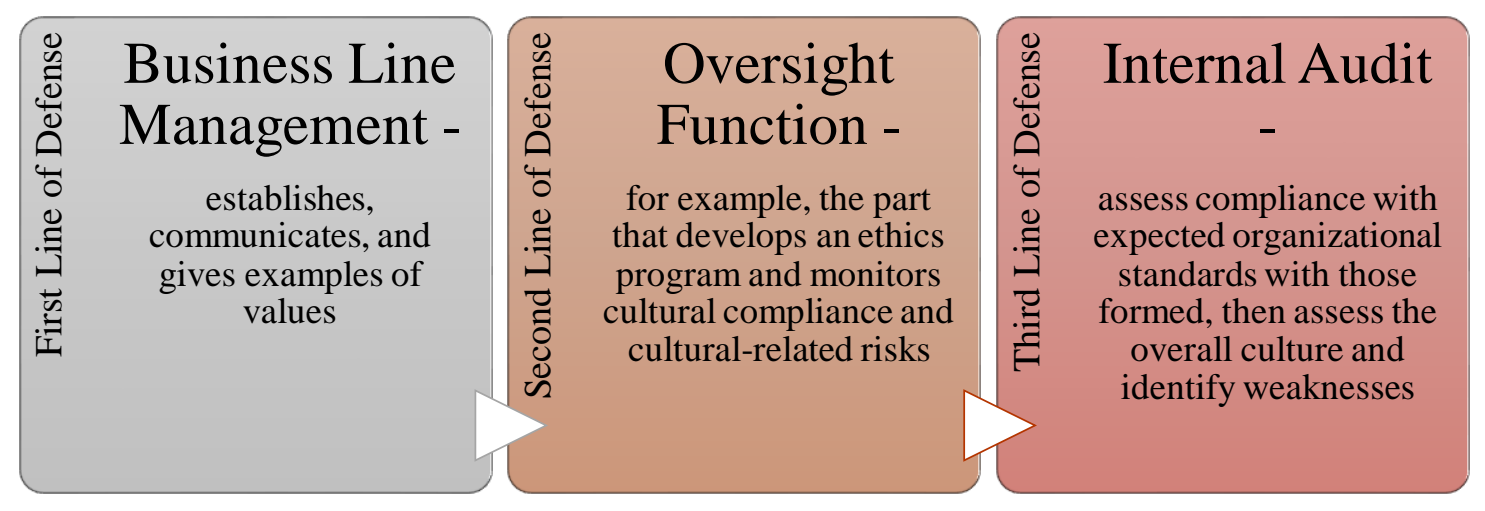

Figure 2 Three Line of Defense at Culture

Source: Global Views and Insights: Cultural Auditing - A Hard Look at the Soft Stuff

(The IIA, 2016b, p.5)

\section{The Development of Previous Research}

Rizaldi (2015) states that leadership from the head of government has a positive impact on improving the control environment and implementing internal controls. Research by Rusnindita \& Baridwan (2017) also shows that leaders' support for attention and proactive involvement influences the quality of the Government's Internal Control System. Lu \& Cao (2018) in his research reaffirmed the existence of interrelated relationships between individual characteristics of top-level leaders towards weak internal controls, even according to research they demanded internal control accountability to the board of directors with assistance from the board of commissioners and management could benefit internal control. Then the research of 
Shu et al., (2018) also shows that integrity and moral values have a significant impact on the quality of internal control.

The studies that have been conducted further show the factors that have an impact on the quality of internal control, where these factors are the principal elements in the control environment component. Current research will emphasize how organizational culture and values are translated into daily behavior, and whether there is a gap between the organizational culture that wants to be embedded with what is carried out in the organization and how it affects the internal control of the organization itself.

\section{The Theory}

Theory of Planned Behavior (TPB) describes attitudes, subjective norms, and perceptions of control behavioral that can influence the desire to behave (Rusnindita \& Baridwan, 2017). Based on this theory there are 3 (three) dimensions that determine the intention of an individual which will ultimately influence the behavior of the individual. These three dimensions (Ramdhani, 2011), first: attitudes toward behavior, namely beliefs about a consequence of the behavior carried out or merely the beliefs of individual behavior towards the environment. Second, subjective norms which are perceptions of individuals regarding the expectations of influential people in their lives whether or not certain behaviors are carried out. The third is the perception of behavioral control regarding the perceptions of each related to natural or difficult to realize a particular behavior. This theory will be used to analyze how employees behave in forming a culture in their environment or vice versa, and also the role of the leader in forming the behavior of their subordinates.

\section{Research Methodology Research Strategies}

Phenomenon concerning organizational culture is one of the essential elements included in the audit program by internal audits, and how organizational culture can affect internal control, and how the leadership role is vital in shaping organizational culture are questions that will be answered with this research. Therefore, the research strategy used is a case study in order to explore this phenomenon with more in-depth analysis, as explained by Yin (2003) that a case study is used to answer the question "how" or "why" that is proposed regarding a series of contemporary events where researchers have little or no control. The unique strength of the case study is its ability to handle a variety of variations of evidence, such as documents, artifacts, interviews, and observations; beyond what might be available in general historical studies (Yin, 2003).

The research approach used is qualitative, a series of interpretation techniques to try to describe, decode, translate, or vice versa, which is related to the meaning, not the frequency that arises from the existence of naturally occurring phenomena in the social world (Cooper \& Schindler, 2014). Research with this qualitative approach aims to achieve a deep understanding of a situation or phenomenon, which can explain why it can happen. The collection of data or evidence used in this study is a combination of primary data and secondary data. The primary data collection method is a method of collecting data from sources for specific purposes from this research that can be collected (Sekaran \& Bougie, 2016). Primary data is obtained directly from the Directorate of Internal Compliance and Transformation of Apparatus Resources (KITSDA) which oversees internal control in DGT, as well as sample employees of KPP Pratama Jakarta through interviews semi-structured, and also through documentation in the form of data relating to internal control at DGT and organizational value invested in the organization.

\section{Data Analysis}

The analytical method used in interpreting the data obtained to obtain answers to the research questions is content analysis. According to Berelson (1952) and Robson 
(2002) content analysis is an analysis carried out both on the content and context of a document by identifying themes, where researchers focus on how the theme is presented or the frequency of its appearance, then associated with "external variables" (Ritchie \& Lewis, 2003). The unit of analysis in this study is the DGT head office as policymakers and regulations related to internal control and organizational values, and sample KPP Pratama Jakarta Xxxx as the implementing unit of the policies and values of the organization that the central leadership wants to instill.

\section{Results}

\section{Interview Results in Unit Analysis}

Based on interview activities conducted randomly to employees in the research unit found several main points related to organizational culture, the role of leaders, and internal control, namely:

1) Organizational Culture

\section{Key points of findings}

- There are different understandings of organizational culture among employees.
Supporting answers

The code of ethics and organizational culture become a rule based on the habit of doing a job or work culture.

$\checkmark$ Organizational culture is related to the values set by the organization, so emphasizing the culture desired by the organization. Besides what has been going on every day it is also called the culture of the organization.

- There are 2 (two) types of organizational culture that arise within organizational units, namely the values that have been determined and want to be instilled by the organization, and habits that exist within an organizational unit which ultimately become a culture

- The organizational culture that is more dominant in units according to the majority (sample) employees is a culture that arises because habits are often done and eventually become a culture. One form of these habits is carried out on the implementation of work that has no Standard Operating Procedure (SOP).

- The absence of supervision is one of the factors that cause the organizational culture to emerge that is dominated by the behavior habits of members of the organization.

- The surrounding environment; both fellow employees and superiors directly influence how employees behave and ultimately can form a habit as a culture $\checkmark$ Organizational culture is the following values that can reflect the core of their business.

$\checkmark$ The character that exists in an organization that can distinguish from other organizations.

$\checkmark$ Habits that exist in the organization environment.

$\checkmark$ As long as the work experience in the unit shows habits more dominant. In the unit what is done based on the habits.

$\checkmark$ more dominant to what has happened, meaning culture that has taken root, which arises because of habits and may not necessarily be true.

$\checkmark$ If seen from the dominant, it is still more dominant how we usually do it in units, but do not forget values and trying to implement SOP

$\checkmark$ Overall, some work systems already have SOPs, but some work systems also do not have SOPs

$\checkmark$ There is no supervision from the highest supervisor or may feel there is no risk if the habit is carried out continuously because if there is a monitoring mechanism, it will not be repeated again

$\checkmark$ The oversight mechanism may be present but still lacking. Besides, the environment and our own are also the cause of

$\checkmark$ Based on previous work experience, the majority work environment helped shape how employees behaved. If the environment holds tights to the values of the organization and the majority runs all of these things, then all others will follow (follow along). Likewise, what happens if the opposite, but returns to each individual but usually like that 
2) Role of Leaders

\begin{tabular}{|c|c|}
\hline Key points of findings & Supporting answers \\
\hline $\begin{array}{l}\text { - The influence of leaders to shape the } \\
\text { organizational culture that the organization } \\
\text { wants to implement itself is very important } \\
\text { and has a very positive effect on employee } \\
\text { behavior which is his subordinates. Because } \\
\text { of the leader of the unit who can create an } \\
\text { environment that supports employees to } \\
\text { work well and implement values and } \\
\text { existing codes of ethics. }\end{array}$ & $\begin{array}{l}\checkmark \text { An organization can be influenced by the ability of } \\
\text { leaders (leadership) to create a tone or atmosphere in } \\
\text { the organization as expected by the leadership so that } \\
\text { the big goals of the organization can be achieved with } \\
\text { maximum. } \\
\checkmark \text { motivation from the outside that is around us like our } \\
\text { boss too, and the climate from the office. The climate } \\
\text { to invite change is what is desired, namely to change } \\
\text { together as a whole office not individually. }\end{array}$ \\
\hline $\begin{array}{l}\text { - The characteristics of the leadership } \\
\text { determine in creating an organizational } \\
\text { culture or work environment of the } \\
\text { organizations. }\end{array}$ & $\begin{array}{l}\checkmark \text { An employee that experience } 2 \text { (two) different } \\
\text { periods of leadership state that their character is very } \\
\text { contradictory, which was previously to the type of } \\
\text { bureaucrat while the present does not show directly } \\
\text { to us that "I am the boss" and also employees will be } \\
\text { embraced first. } \\
\checkmark \text { The leadership model, the leadership style in } \\
\text { delegating tasks, the personal approach to employees } \\
\text { influences the comfort and morale of employees. }\end{array}$ \\
\hline $\begin{array}{l}\text { - Implementation of Tone at The Top in the } \\
\text { unit has not been well implemented } \\
\text { according to some employees, but } \\
\text { according to some other employees it has } \\
\text { been carried out by the leader. }\end{array}$ & $\begin{array}{l}\checkmark \text { leaders who before and also at present are still not } \\
\text { maximal in implementing the tone at the top. } \\
\checkmark \text { There are some that are good, but some are slightly } \\
\text { less. For example, the leadership of the moment, he } \\
\text { is the type that is somewhat relaxed so that } \\
\text { subordinates also think that they can relax and do } \\
\text { whatever they want. } \\
\checkmark \text { to give examples of the implementation of the } \\
\text { organizational values and codes of conduct, he did by } \\
\text { coming up and return in accordance with the business } \\
\text { hours. }\end{array}$ \\
\hline $\begin{array}{l}\text { All respondents employees agree that the } \\
\text { top leader in the unit provide support and } \\
\text { can be invited to discuss together to resolve } \\
\text { the problems faced by employees }\end{array}$ & $\begin{array}{l}\checkmark \text { In this unit, direct superiors provide support to } \\
\text { employees if faced with a problem, even the } \\
\text { leadership of the unit also helps and backs up } \\
\text { employees. } \\
\checkmark \text { While working in this unit, co-workers help each } \\
\text { other by sharing and finding solutions together. If it } \\
\text { is not resolved, the supervisor is immediately ready } \\
\text { to give advice, even the head of the office is ready to } \\
\text { help solve the problem. }\end{array}$ \\
\hline $\begin{array}{l}\text { " "Knowing Your Employee," which is felt } \\
\text { by most employees in the unit. Besides, the } \\
\text { top head of the unit also conducts personal } \\
\text { assessments to employees based on their } \\
\text { real performance in the field. }\end{array}$ & $\begin{array}{l}\checkmark \text { In this unit, there are activities like eating together } \\
\text { one section or meeting once a month that can actually } \\
\text { be used to give examples to employees and also to } \\
\text { know personally about their subordinates, the same } \\
\text { as knowing your taxpayer. } \\
\checkmark \text { Performance evaluation here uses IKU or e- } \\
\text { performance, but the unit leader also knows about the } \\
\text { quality of the performance of his employees. This can } \\
\text { be seen in determining the value of grading S, A, B, } \\
\text { C, D for each employee who can vary because it is } \\
\text { determined directly by the top head of the unit. } \\
\checkmark \text { The top leader pay attention by going to each section } \\
\text { to find out the conditions that are happening or asking } \\
\text { tax case progress handled by employees }\end{array}$ \\
\hline
\end{tabular}




\begin{tabular}{|c|c|}
\hline Key points of findings & Supporting answers \\
\hline $\begin{array}{l}\text { - Internal control systems in the unit still lack } \\
\text { implementation according to most } \\
\text { employee respondents. The Internal } \\
\text { Compliance Unit (UKI) in the unit does not } \\
\text { work as what employees know about } \\
\text { internal control. }\end{array}$ & $\begin{array}{l}\checkmark \text { Control in the unit that is still felt is work that has the } \\
\text { maturity, but for cultural-related internal controls } \\
\text { such as sudden inspection of employee's attributes are } \\
\text { not seen here. } \\
\checkmark \text { the perceived difference compared with the previous } \\
\text { unit is not never seen doing periodic reports on the } \\
\text { risk management. } \\
\checkmark \text { system of internal control in units already exist but } \\
\text { need to be improved too, especially on supervision by } \\
\text { superiors and supervision from friends. }\end{array}$ \\
\hline $\begin{array}{l}\text { - Characteristics of the leader affecting the } \\
\text { implementation of the internal control } \\
\text { system in an organizational unit. }\end{array}$ & $\begin{array}{l}\checkmark \text { if top management or management is less strict, } \\
\text { internal control becomes more loose, even though the } \\
\text { goal is that employees are not depressed and can work } \\
\text { well so that revenues can be achieved. Especially } \\
\text { employee discipline problems are still not strict. } \\
\checkmark \text { Leisurely leadership does not mean that he does not } \\
\text { work, it is only his character, but subordinates see it } \\
\text { as free as there are no boundaries. }\end{array}$ \\
\hline $\begin{array}{l}\text { - Between organizational culture and internal } \\
\text { control has interrelated relationships, not } \\
\text { just one direction. }\end{array}$ & $\begin{array}{l}\checkmark \text { The lead character will influence how control internal } \\
\text { applied in a unit. Because the rules made are standard } \\
\text { and firm, there is no compromise so that when the } \\
\text { leader is easy going and compromise the rules can } \\
\text { also turn. } \\
\checkmark \text { Internal control is needed by the organization so that } \\
\text { the culture of the organization that wants to be } \\
\text { instilled can run. } \\
\checkmark \text { Internal control is needed to monitor and assess } \\
\text { whether the dominant habits occur; it is a good habit } \\
\text { or bad habit that cannot be carried out. }\end{array}$ \\
\hline
\end{tabular}

Interview Results from Internal Auditor

\begin{tabular}{l|l}
\hline \multicolumn{1}{c|}{ Key points of findings } & \multicolumn{1}{c}{ Supporting answers } \\
\hline $\begin{array}{l}\text { Internal control systems in the organization } \\
\text { have implemented an internal control } \\
\text { framework according to COSO which } \\
\text { consists of 5 (five) elements }\end{array}$ & $\begin{array}{l}\checkmark \text { SPI in the organization already implemented an } \\
\text { internal control framework according to COSO } \\
\text { which consists of 5 (five) levels in accordance with } \\
\text { regulations governing the internal control system }\end{array}$ \\
\hline $\begin{array}{l}\text { Doing monitoring or supervision of risky } \\
\text { business processes }\end{array}$ & $\begin{array}{l}\text { in the internal compliance section focuses on the } \\
\text { level of monitoring, i.e., monitoring risky business } \\
\text { processes. UKI assists monitoring in each vertical } \\
\text { unit }\end{array}$ \\
$\begin{array}{l}\text { - Internal auditors are also very concerned } \\
\text { about the importance of organizational } \\
\text { culture to internal control. }\end{array}$ & $\begin{array}{l}\text { Internal control does not need to work hard if the } \\
\text { organizational culture has been proven to run well } \\
\text { from top to bottom. Because organizational culture is } \\
\text { an element at the lowest level, namely as control } \\
\text { environment so that if the lowest level is good, then } \\
\text { the next level will also be good. }\end{array}$ \\
$\begin{array}{l}\text { Various ways are carried out by internal } \\
\text { auditors related to organizational cultural } \\
\text { values and ethical codes, namely: } \\
\text { monitoring compliance with a code of ethics } \\
\text { routinely, internalizing cultural values and } \\
\text { codes of ethics, conducting surveys of } \\
\text { understanding and commitment of } \\
\text { employees towards the code of ethics and } \\
\text { organizational culture. }\end{array}$ & $\begin{array}{l}\text { For the control environment carried out internalizing } \\
\text { organizational cultural values and ethical codes as } \\
\text { well as possible in each vertical unit. } \\
\text { There is an assessment for the unit vertical related to } \\
\text { the implementation of organizational culture and } \\
\text { initiative from the leadership of the unit. } \\
\text { There is a report on the code of ethics that assesses } \\
\text { only the formal procedure. }\end{array}$ \\
\end{tabular}


$\checkmark$ survey of employees used as a tool to measure employee understanding and commitment as an evaluation understanding and commitment to the code of ethics and organizational culture.

\section{Documentation}

DGT as an organization also has a section or directorate whose duty is to supervise organizational values, and the code of ethics has been carried out as stipulated. The directorate in question is the directorate of Kitsda. One form of effort to Strengthen Organizational Culture made by the Compliance Internalization sub-division at the Kitsda directorate is regarding the Implementation of the Corporate Value Internalization Program in 2019 through the Service Note number: ND-193 / PJ / 2018 dated December 31, 2018, which is aimed at all units in DGT The Service Note was issued as a manifestation of the implementation of the Minister of Finance Decree number 312 / KMK.01 / 2011 concerning the Ministry of Finance Values. The ND explained about the 5 (five) values of the Ministry of Finance, namely Integrity, Professionalism, Service, Synergy, and Perfection along with an explanation of each program in accordance with the values of the Ministry of Finance which became an internalization program at the DGT.

\section{Discussion}

\section{Effect of Organizational Culture on the Effectiveness of Internal Control}

In the findings, it is known that the role of organizational culture in a unit has a significant influence on the effectiveness of internal controls in the unit. Organizational culture has the responsibility to shape and maintain the perceptions of employees and the behaviors they approve, so that if this has gone according to what the organization wants, the internal control in the unit will be effective. Organizational culture is expected to be a soft source of control so that it can support the effectiveness of internal control of an organizational unit. However, in the practice that runs in the unit, it is known that the organizational culture that is formed is more dominated by habits that are often carried out or have not fully followed the values of the organization to be embedded in the organization. Some of the causes are that in some of the work carried out there are still no SOPs, a lack of supervisory mechanisms carried out by superiors, and their work environment that can be influenced by fellow employees and direct superiors.

Based on these cases, it shows that the internal control system in the unit has not gone well, because it cannot catch the emergence of these problems in the unit. This can be seen up to now the organizational culture because of the habits that are formed, not the organizational culture that is by the values of the organization and the code of ethics that want to be instilled. This phenomenon shows that a strong organizational culture is supported by a strong internal control system, whereas if seen based on the internal control framework according to COSO the existence of a strong organizational culture is the foundation for the establishment of an effective internal control system. This phenomenon that wants to be explained in a previous study by Domnisoru et al., (2017) that the influence of organizational culture is not only on the most basic internal control elements, namely the control environment, but on the overall elements of internal control, in other words, organizations with a culture of ethics do not need stronger monitoring to their employees but not using manual procedures, but on the other hand internal control can affect the organization's culture itself, namely changing certain elements that are part of the culture (rules, habits, how to communicate). 


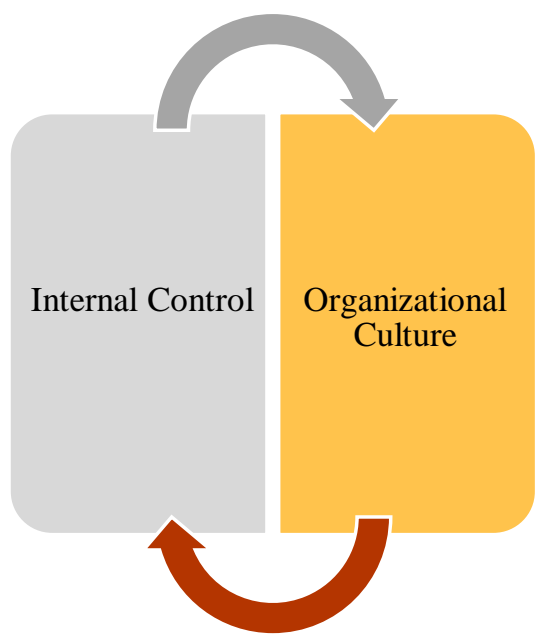

\section{Figure 3 The relationship between internal control and organizational culture base on this case}

The picture above reflects the relationship formed between internal control and organizational culture in the unit. Dominant organizational culture is a culture that arises because of behavioral habits that occur due to lack of supervision or monitoring in this case the internal control mechanism is felt to be lacking. However, one of the factors that influence an effective internal control system is the characteristics of the leader in creating a climate or atmosphere that is part of the organization's culture itself also determines how the overall internal control is implemented in the unit.

Based on the findings of organizational culture and internal control, habits that are more dominant in the behavior of everyday employees form the culture of the unit if according to the Theory of Planned Behavior, arise because of the following elements: a) Attitudes toward behavior are influenced by beliefs of consequences for behavior. Employees know and understand that their behavior is not following organizational values, but because there is no risk to be borne if they do not do it and so far it is fine when they do it, they conclude that there is nothing wrong with this behavior.

b) Subjective norms that can arise from the presence or absence of expectations of people around who influence their to do or not a behavior. If the environment around them, namely fellow employees or direct superiors also does not show behavior that is following the values of the organization, it further strengthens their attitude towards the behavior they will take and carry out. The confidence of each employee to implement all the values of the organization exists, but when he feels that he wants to change only himself, but the environment (fellow employees and superiors) does not change, then that belief is only an intention without being implemented.

c) Control behavior focuses on individual perceptions regarding whether or not it is easy to carry out certain behaviors. This will be well followed by employees if in reality the employee can see the boss directly or the leader also performs the behavior. So if he does not do it, it will be a concern for his boss. It appears that the leadership role in applying the tone from the top influences their decisions in behaving within the organization.

These three elements influence the intentions of individual employees in considering and ultimately deciding the behavior they will carry out in their daily working lives. This theory reinforces that the existence of good oversight and role models in an organizational environment can influence the individual judgment in deciding to behave. 


\section{The Role of Top Leaders in Creating Organizational Culture}

The importance of the role of leadership has been emphasized in the most basic element of the internal control framework according to COSO, namely the control environment. Based on the findings of the research unit, it shows that the role of the leader is very influential in shaping the organizational culture as desired because leaders can create a climate that invites members together towards good change. The influence of the leadership role is very felt by employees based on the individual characteristics of each of the leaders, namely leadership style, how to delegate tasks, and personal approach. Because different characteristics will create an atmosphere or different cultural conditions. The atmosphere or tone that the top leader wants to set through their actions or behavior becomes the standard for his subordinates to behave. If the leader gives a good example, the subordinates will follow according to the example.

Based on the data obtained through ND regarding the internalization of organizational values, it is known that there are 2 (two) cultural programs related to the leadership role, namely Strengthening the Exemplary Leadership Program and Knowing Your Employee. The strengthening of the Leadership Exemplary program shows that it is felt that there is still a lack of examples of behavior because the character of the leader whose disposition is easy going, gives an assumption to employees that they can relax and act arbitrarily, thus influencing their behavior and ultimately affecting the system control in a unit. While the purpose of such leaders is so that employees are not depressed in achieving the target so that they can optimally achieve results. Even so, it turns out that this has a negative influence on the effectiveness of internal control in the unit. When the leadership of a unit has characteristics, easy going it affects the implementation of internal controls to be more lenient.

While some respondents felt that the leadership had given a role model, one of them was by wearing full clothing attributes of employees and obeying office hours. Then for program KnowingYour Employee has been well implemented according to the answers from the respondents. This is because unit leaders always provide support and solutions when their employees experience a problem in their work, then the leader has a way of evaluating the performance of each employee who distinguishes between one employee and another employee, and a personal approach to employees is carried out by having shared meals with each part in the unit.

\section{The Role of Internal Auditors Regarding Organizational Culture in Internal Control}

Regarding the importance of the influence of organizational culture on internal control has been a concern for internal auditors in the organization. This is done with one of them issued the ND-193 / PJ / 2018 dated 31 December 2018 concerning instructions for implementing the internalization of cultural values. The existence of the ND can facilitate vertical units to implement existing cultural programs, and also regulate the provisions that must be followed by vertical units in carrying out team building activities. Also, a survey on the understanding and commitment of employees towards the code of ethics and organizational values was also carried out to map out the lack of cultural programs and codes of ethics, and special attention should be given to subsequent monitoring.

However, reports relating to organizational culture and the code of ethics only emphasize whether the attributes related to it and existing programs have been carried out or not under existing regulations. The current role of internal auditors is only to evaluate the compliance of each organizational unit in carrying out the values and code of ethics that have been determined. It can be said to be more procedurally or formally fulfilling the provisions without delving deeper into whether there is a gap between the expected with a culture that is formed and identifies these weaknesses. 
Internal auditors in this organization have not carried out their functions as giving adequate assurance that the organizational culture that they want to instill is an organizational culture that is formed in vertical units or gives assurance that the organizational culture that is formed will not harm the entire organization. Auditor functions like this are becoming a trend nowadays because of the phenomenon of organizational culture at the root of the problem from the big scandals that happened to the company. If the report carried out cannot capture the culture of what is formed in a unit, it cannot capture the possibility of behavior that is not following the values of the organization. So that prevention cannot be done by improving the current culture in order to create an effective internal control system.

\section{Conclusion}

This study shows that the influence of organizational culture on an organization's internal control system is very significant. If the actual organizational culture formed in the organizational unit is following the organizational culture that the organization wants to instill, the internal control system will be more effective in its implementation. This is because a strong organizational culture has helped alleviate internal implementation because of the risks arising from differences in cultural values between individuals and organizations, namely behavior that is not expected by the organization to be insignificant or even non-existent. In this study shows that organizational culture formed in the unit is still more dominant to how they usually do something compared to the culture they want to instill by the organization, and one of the causes is still a lack of supervision from direct supervisors or unit leaders.

This happened not because the internal control system of the unit was weak, but the role of the leadership in forming an organizational culture that was felt still lacked by his subordinates. Because the role of top management in units can create an atmosphere or condition in accordance with the desired culture by implementing soft controls including behavior and attitudes, namely, such as strong leadership, trust and openness, and sharing values. The behavior and attitudes of the leadership itself are soft controls that need to be improved, and this must be started from the top leader of an organizational unit, that is if the company starts with the board of directors. Top level leaders need to have a responsibility regarding the application of the tone at the top in the organization to run well at the middle level (tone at the middle) until finally conveyed to subordinates who aim to instill values desired by the organization into subordinate behavior. If this happens, internal control can run more effectively because each member of the organization has the same awareness and value as the organization. Therefore, the role of the current internal auditor is not only as give advice on the control of what needs to be improved but also providing adequate assurances to the top management related to the organizational culture that is actually formed by what is expected by the organization. That assurances consist of the function of tone from the top has been running well and felt by all employees, that no risk could arise from the actual organizational culture that was formed that can threaten the survival of the organization by conducting an audit culture.

\section{Limitations of the Research}

The limitations of this study are only carried out in 1 (one) sample unit as the object of research to evaluate and evaluate whether internal control has been running well concerning the influence of organizational culture formed in the unit, especially regarding the role of leadership in the unit. Another limitation is that the focus of this research is on the role of top leaders, will be very helpful in exploring existing phenomena by conducting interviews with top-level leaders in DGT organizations regarding their roles and responsibilities for planting organizational values and the importance of internal control in achieving organizational goals from the leader's point of view. Researchers find it difficult to conduct interviews with top-level leaders, which are caused by bureaucratic processes in obtaining appropriate permits and schedules. 


\section{Recommendation for Further Study}

Research can be conducted on more than 1 (one) sample unit so that it can better reflect the overall organizational culture created in the field, so that based on the results obtained can be evaluated related to the organization's overall internal control system not only the internal control system only specific units. Then regarding the risk factors that can influence the emergence of differences between cultures that are actually formed with the culture that is to be instilled, apart from the leadership element, namely tone at the top, which can be added in the focus of the research is the mechanism of risk culture (risk management framework), incentives, or accountability and strengthening.

\section{References}

Cahyasari, W. F. (2018). Empat Belas Juli, Awal Sejarah Reformasi Perpajakan. Retrieved February 20, 2019, from http://www.pajak.go.id/article/empat-belasjuli-awal-sejarah-reformasi-perpajakan

CIIA. (2014a). Audit Committee Briefing Culture and the role of internal audit looking below the surface. London. Retrieved from https://www.iia.org.uk/resources/ethics-values-and-culture/organisationalculture/research-report-culture/

CIIA. (2014b). Culture and The Role of Internal Audit: Looking Below The Surface. London. Retrieved from https://www.iia.org.uk/resources/ethics-values-andculture/organisational-culture/research-report-culture/

CIIA. (2016). Organisational Culture: Evolving approaches to embedding and assurance. London. Retrieved from https://www.iia.org.uk/resources/ethicsvalues-and-culture/organisational-culture/research-report-culture/

Clayton, S., \& Wisdom, J. (2019). Company culture needs a risk-management approach. Retrieved February 18, 2019, from https://qz.com/work/1546621/company-culture-needs-a-risk-managementapproach/

Cooper, D. R., \& Schindler, P. S. (2014). Business Research Methods (Twelfth Ed). New York, America: McGraw-Hill/Irwin.

COSO. (2013). Internal Control — Integrated Framework Executive Summary, (May). Retrieved from www.coso.org

Deloitte. (2012). Cultivating a Risk Intelligent Culture Understand, measure, strengthen, and report Process follows culture. Chicago. Retrieved from https://www2.deloitte.com/content/dam/Deloitte/us/Documents/center-forcorporate-governance/us-ccg-cultivating-a-risk-intelligent-culture-050212.pdf

DJP. (2012). Reformasi Birokrasi Untuk Kesejahteraan Masyarakat. Retrieved February 20, 2019, from http://www.pajak.go.id/content/reformasi-birokrasiuntuk-kesejahteraan-masyarakat

Domnisoru, S., Ogarca, R., \& Dragomir, I. (2017). Organizational Culture and internal control. Audit Financiar, 4(148), 628-643. https://doi.org/10.20869/AUDITF/2017/148/628

EY. (2015). Risk culture: The Role of Internal Audit. Retrieved from https://www.ey.com/Publication/vwLUAssets/EY-risk-governance-2020-riskculture-the-role-of-internal-audit/\$FILE/EY-risk-governance-2020-risk-culturethe-role-of-internal-audit.pdf 
FSB. (2014). Guidance on Supervisory Interaction with Financial Institutions on Risk Culture: A Framework for Assessing Risk Culture. Retrieved from http://www.fsb.org/2014/04/140407/

IIA. (2016). More Than Just Setting the Tone: A Look at Organizational Culture. Retrieved from https://dl.theiia.org/AECPublic/Tone-at-the-Top-February2016.pdf

Kemenkeu, D. (2017). Laporan Kinerja Direktorat Jenderal Pajak. Jakarta. Retrieved from www.pajak.go.id

Lu, Y., \& Cao, Y. (2018). The individual characteristics of board members and internal control weakness: Evidence from China. Pacific-Basin Finance Journal, 51(April), 75-94. https://doi.org/10.1016/j.pacfin.2018.05.013

Lumbanrau, R. E. (2016). Rentetan Kasus Korupsi yang Menjerat Pegawai Pajak. Retrieved February 27, 2019, from https://www.cnnindonesia.com/nasional/20161122162351-12-174492/rentetankasus-korupsi-yang-menjerat-pegawai-pajak

Moeller, R. R. (2009). Brink's Modern Internal Auditing (Seventh Ed). Hoboken, New Jersey: John Wiley \& Sons, Inc.

Owoyemi, O. O., \& Ekwoaba, J. O. (2014). Organisational Culture: A Tool for Management to Control, Motivate and Enhance Employees' Performance. American Journal of Business And Management, 3(3), 168-177. https://doi.org/10.11634/216796061403514

PWC. (2009). Auditing risk culture. Retrieved from https://www.pwc.com.au/assurance/assets/auditingriskculture_feb09.pdf

Ramdhani, N. (2011). Penyusunan Alat Pengukur Berbasis Theory of Planned Behavior. BULETIN PSIKOLOGI - FAKULTAS PSIKOLOGI UNIVERSITAS GADJAH MADA, 19(2), 55-69. Retrieved from https://jurnal.ugm.ac.id/buletinpsikologi/article/view/11557

Ritchie, J., \& Lewis, J. (2003). QUALITATIVE RESEARCH PRACTICE A Guide for Social Science Students and Researchers (First Edit). London: Sage Publications.

Rizaldi, A. (2015). Control Environment Analysis at Government Internal Control System: Indonesia Case. Procedia - Social and Behavioral Sciences, 211(September), 844-850. https://doi.org/10.1016/j.sbspro.2015.11.111

Rusnindita, K., \& Baridwan, Z. (2017). Determinan Kualitas Sistem Pengendalian Internal Pemerintah. Jurnal Riset Dan Aplikasi: Akuntansi Dan Manajemen, 2(Maret 2017), 141-157. https://doi.org/10.18382/jraam.v2i2.105

Sekaran, U., \& Bougie, R. (2016). Research Methods for Business : a skill-building approach (Seventh Ed). Chichester, West Sussex, United Kingdom: John Wiley \& Sons.

Shu, W., Chen, Y., Lin, B., \& Chen, Y. (2018). Does corporate integrity improve the quality of internal control? China Journal of Accounting Research, 11(June 2008), 407-427. https://doi.org/10.1016/j.cjar.2018.09.002

The IIA. (2013). Governance and Risk Report 2013 IIA Annual Survey. London. Retrieved from https://www.iia.org.uk/media/468878/0784-HIA-AnnualSurvey-31-10-2013.pdf

The IIA. (2016a). GLOBAL PERSPECTIVES AND INSIGHTS : Auditing Culture - A 
Hard Look at the Soft Stuff. Retrieved from https://global.theiia.org/knowledge/Public Documents/2016-Feb-GPIEnglish.pdf

The IIA. (2016b). Pandangan dan Wawasan Global: Mengaudit Budaya - A Hard Look at the Soft Stuff. Retrieved from https://global.theiia.org/translations/PublicDocuments/2016-Feb-GPIIndonesian.pdf

Yin, R. K. (2003). CASE STUDY RESEARCH: Design and Methods (Second Edi). Sage Publications, International Educational and Professional Publisher. 